\title{
Spatial and temporal diversity of wood decomposer communities in different forest stands, determined by ITS rDNA targeted TGGE
}

\author{
Ariana KULHÁNKOVÁa ${ }^{\mathrm{a}, \mathrm{b} *}$, Thierry BÉGUIRISTAIN ${ }^{\mathrm{b}}$, Judicaël MOUKOUMI ${ }^{\mathrm{a}, \mathrm{b}}$, \\ Jacques BERTHELIN ${ }^{\mathrm{b}}$, Jacques RANGER ${ }^{\mathrm{a}}$ \\ ${ }^{a}$ INRA, Centre de Nancy, Unité Biogéochimie des Écosystèmes Forestiers, 54280 Champenoux, France \\ ${ }^{\mathrm{b}}$ LIMOS, CNRS UHP UMR 7137, Université Henri Poincaré, BP 239, 54506 Vandœuvre-les-Nancy, France
}

(Received 3 March 2005; accepted 22 March 2006)

\begin{abstract}
The aim of this study was to determine the dynamics of colonisation and composition of the wood-decomposer community in a native forest and four monocultures over time. A fingerprinting method of TGGE (temperature gradient gel electrophoresis) with rDNA amplified by ITS1F and ITS2 primer pairs was optimized and used as a culture-independent approach to determine the dominant fungal species and biodiversity over a two-year period of decomposition of beech-wood samples. The bacterial community after two years was also investigated. Data showed that each tree species, as well as sampling date, displayed the characteristic community structure. There was no strong decrease in microbial species richness or Shannon-Wiener diversity index caused by a change of tree species. Nevertheless, a strong shift in decomposer community structure was evident among the tree species both for fungi and bacteria. The effect of environmental conditions was also significant.
\end{abstract}

wood / decomposers / forest / ITS / TGGE

Résumé - Étude par TGGE de la diversité spatiale et temporelle des communautés de décomposeurs du bois en fonction des essences forestières. L'objectif de cette étude était de caractériser la dynamique de colonisation d'un matériau modèle (du bois de hêtre) par les lignivores au cours de la décomposition, dans une forêt native et sous quatre essences de substitution à la forêt native feuillue. La technique d'empreinte génétique de TGGE (électrophorèse sur gel en gradient de température) ciblée sur l'ADN ribosomique, amplifié par les amorces ITS1F et ITS2, a été optimisée et utilisée pour déterminer les espèces fongiques dominantes ainsi que la diversité totale au cours des deux années d'incubation in situ des échantillons. La diversité bactérienne a également été étudiée sur les échantillons prélevés après deux années d'incubation. Les données indiquent que le peuplement et la durée d'incubation modifient la structure des communautés fongiques. Il n'y a cependant pas de forte diminution du nombre d'espèces ni de l'index de diversité de Shannon-Wiener associée au changement d'essence forestière. Toutefois, il y a une forte évolution dans la structure des communautés de décomposeurs entre les peuplements, à la fois pour les champignons et les bactéries. Les effets des paramètres environnementaux sont discutés.

bois / lignivores / forêt / ITS / TGGE

\section{INTRODUCTION}

A significant part of European forests has been replaced by even-aged plantations of native or alien tree species, especially during the last century. Such large changes modify soil conditions such as microclimate or organic and mineral chemistry of the litter. This can significantly influence the abundance, structure and activity of the soil microbial community regarding its and, thus, the functional integrity of the forest soil.

Plant litter decomposition is an important factor controlling organic matter decay, nutrient turnover and humus formation in forest ecosystems. It is also relevant at the biosphere level, because decomposition releases significant amounts of greenhouse gases. Thus, soil organic matter represents a major sink for carbon [6]. Therefore, research of belowground species diversity, with respect to the environment and microbial activity, is required to achieve a full understanding of forest ecosystem functioning. It is an important goal in regards to sustainable

\footnotetext{
*Corresponding author: arikul@centrum.cz
}

forestry as well as having a potential role in global climate change.

The decay activity is expected to be positively related to the number of decomposer taxa. Even recalcitrant substrates, such as lignin, should degrade faster in diverse systems relative to simple ones, probably due to the complementary roles of different fungal species [26]. Fungal succession during litter decomposition has been recently studied for several forest floors under different tree species [22, 27,31].

However, the dynamics of complex systems are not easy to describe. The behaviour of a single, isolated species or a simple community in a micro- or mesocosm study might not reflect its behaviour in a more complex natural environment. The use of model material decomposing in a tree monoculture could be a possible way to control variability by decreasing the effects of total natural complexity.

Suitable molecular techniques to study microbial species composition are based on direct extraction of DNA from environmental samples, thereby circumventing the culturing step 
and giving a more realistic view of total diversity [1]. The use of internal transcribed spacer (ITS) primers to amplify fungal ITS of rDNA was originally described by White et al. [32] and pioneered by Gardes et Bruns [9]. Studies based on the ITS region showed that intraspecific variation was very small when studying fungal isolates from the same geographical area, while interspecific variation was large enough to distinguish different species [16]. Moreover, analysis of the ITS region was more specific and taxonomically more informative than other genomic regions (e.g. 18S) [19]. Molecular methods to describe microbial succession were used in different studies, e.g. for investigating the decomposition of spruce and pine litter across a moisture gradient [33], beech and spruce litters [3] or to study wood-inhabiting fungi $[14,15,29]$.

The present study deals with microbial colonisation of wood samples incubated for two years below five different tree species under the same ecological conditions. The first objective was to improve the method of ITS1F and ITS2 targeted TGGE. It was hypothesized that the samples would show differences in decomposer patterns when compared (i) between native forest and corresponding broadleaved plantations, (ii) among forest species and (iii) within the duration of the decay process. We also expected to identify the key species which characterise the stands, as well as the temporal succession.

\section{MATERIALS AND METHODS}

\subsection{Site description}

The experimental site of Breuil-Chenue forest is situated in the Morvan Mountains, Burgundy, France. Its altitude is $640 \mathrm{~m}$, latitude $47^{\circ} 18^{\prime} 10^{\prime \prime}$ and longitude $4^{\circ} 4^{\prime} 44^{\prime \prime}$. Mean annual temperature is $9^{\circ} \mathrm{C}$, with $1280 \mathrm{~mm}$ precipitation and evapotranspiration of $640 \mathrm{~mm}$. The substrate is granite with desaturated acid soil ( $\mathrm{pH} 4-4.5,60 \%$ of sand, $20 \%$ of clays). The natural potential vegetation would be a mixed broadleaf forest. It evolved with management towards a semi-natural coppice with a forest dominated by Fagus sylvatica L. and Quercus sessiliflora Smith, associated with several other dominant species like Betula verrucosa Ehrh. and Corylus avelana L. This native forest was partially cut down in 1976 and replaced by various monocultures planted in $1000 \mathrm{~m}^{2}$ plots each. Five different stands were selected for the treatment: four young plantations, namely beech (Fagus sylvatica L.), oak (Quercus sessiliflora Smith.), Norway spruce (Picea abies Karst.) and Douglas fir (Pseudotsuga menziesii Franco.) and the native forest as a reference plot. All of these stands had the same environmental conditions. Thus, all variations in physical and chemical properties are expected to be caused by the forest tree species. For the same reasons, changes in the biological characteristics, such as the structure, of the decomposer community were supposed to be driven by the tree species.

\subsection{Field experiment}

Beech-wood pieces $(4.5 \times 3.5 \times 0.5 \mathrm{~cm})$ were incubated in the five different forest stands using the classical litter-bag method. Mesh size of the bags was $5 \mu \mathrm{m}$ and the inside area $5 \times 5 \mathrm{~cm}$. The distance between two replicates was $0.5 \mathrm{~m}$ and $1.5 \mathrm{~m}$ between two blocks. The bags were placed in the stands in late November 2002. They were collected after either 3, 9, 12 or 24 months (February, September and November 2003, and early December 2004). Three replicates were sampled and stored in a deep freezer until analysis.

\subsection{Molecular analyses}

The surface layer, including mostly fungal mycelia and a small amount of degraded wood, was scraped from each sample. Total genomic DNA was isolated from these prepared samples using the Dneasy plant mini kit (Qiagen) following the manufacturer's protocol without any modification.

Fungal communities were analysed using ITS1F and ITS2 primer pairs to amplify by PCR the $300 \mathrm{bp}$ fragment of the fungal ITS rDNA. The primer ITS1F (5'-CTT GGT CAT TTA GAG GAA GTA A-3') [13] is higher fungi ITS specific, while ITS2 (5'-GCT GCG TTC TTC ATC GAT GC-3') is a universal primer amplifying the ITS region from Eucaryotes, including both Ascomycetes and Basidiomycetes [32]. A $40 \mathrm{bp} \mathrm{GC-clamp} \mathrm{was} \mathrm{attached} \mathrm{to} \mathrm{the} \mathrm{5'} \mathrm{end} \mathrm{of} \mathrm{the}$ primer ITS2 to avoid a complete separation of DNA strands during denaturing electrophoresis. The reaction medium consisted of $5 \mu \mathrm{L}$ of PCR buffer (Sigma, $100 \mathrm{mM}$ Tris-HCl, $\mathrm{pH} \mathrm{8.3,500} \mathrm{mM} \mathrm{KCl,}$ $15 \mathrm{mM} \mathrm{MgCl} 2), 1 \mu \mathrm{L}$ of dNTP $(10 \mathrm{mM}), 1 \mu \mathrm{L}$ of each primer $(20 \mu \mathrm{M}), 0.5 \mu \mathrm{L}$ of Taq-polymerase ( 5 units/ $\mu \mathrm{L}$, Sigma), $1 \mu \mathrm{L}$ of GCrich solution (Sigma) and $2 \mu \mathrm{L}$ of genomic DNA brought to a final volume of $50 \mu \mathrm{L}$. The amplification regime consisted of an initial cycle of denaturation at $95{ }^{\circ} \mathrm{C}$ for 3 min followed by 35 cycles of denaturation at $94{ }^{\circ} \mathrm{C}$ for $45 \mathrm{~s}$, annealing at $55^{\circ} \mathrm{C}$ for $45 \mathrm{~s}$ and extension at $72{ }^{\circ} \mathrm{C}$ for $1 \mathrm{~min} 15 \mathrm{~s}$. The amplification concluded with a final elongation step at $72{ }^{\circ} \mathrm{C}$ for $8 \mathrm{~min}$.

Bacterial communities were analysed using the eubacterial primer set, 968f and 1401r, to amplify by PCR a 475-bp fragment of $16 \mathrm{~S}$ rDNA from the same DNA extract as above [13]. A 40-bp GC clamp was attached to the 5' end of the primer 968f. A $50 \mu \mathrm{L}$ PCR mixture containing $5 \mu \mathrm{L}$ of PCR buffer (Sigma, $100 \mathrm{mM}$ Tris- $\mathrm{HCl}, \mathrm{pH}$ $8.3,500 \mathrm{mM} \mathrm{KCl}), 1 \mu \mathrm{L}$ of dNTP $(10 \mathrm{mM}), 1 \mu \mathrm{L}$ of each primer $(100 \mu \mathrm{M}), 0.5 \mu \mathrm{L}$ of Taq-polymerase (Fastart, Roche Diagnostic), $2 \mu \mathrm{L}$ of $\mathrm{MgCl}_{2}, 1 \mu \mathrm{L}$ of GC-rich solution (Sigma), $2 \mu \mathrm{L}$ of BSA (3\%) and $2 \mu \mathrm{L}$ of genomic DNA was used. The amplification regime consisted on an initial cycle of denaturation at $94{ }^{\circ} \mathrm{C}$ for $5 \mathrm{~min}$, followed by 35 cycles of denaturation at $94{ }^{\circ} \mathrm{C}$ for $40 \mathrm{~s}$, annealing at $56{ }^{\circ} \mathrm{C}$ for $30 \mathrm{~s}$ and extension at $72{ }^{\circ} \mathrm{C}$ for 1 min concluded with an elongation step at $72{ }^{\circ} \mathrm{C}$ for $5 \mathrm{~min}$.

All PCR reactions were performed using an iCycler Thermal cycler (Biorad). PCR products( $7.5 \mu \mathrm{L}, 1.5 \mu \mathrm{L}$ of loading buffer) were loaded onto $1.5 \%(\mathrm{wt} / \mathrm{vol})$ agarose gels and electrophoresed $(1 \times \mathrm{TAE}$ buffer, $110 \mathrm{~V}, 45 \mathrm{~min})$. Then the gels were stained with ethidium bromide $(0.5 \mathrm{mg} / \mathrm{L}$, Biorad $)$ and the DNA bands visually inspected under UV light to verify the size and quality of the generated amplicons.

TGGE was performed with a Dcode Universal Mutation Detection system (Biorad). In the case of fungi, polyacrylamide gels ( $(8 \%$ acrylamide (wt/vol), $8 \mathrm{M}$ urea, $1.25 \times$ TAE and $0.2 \%$ glycerol $(\mathrm{vol} / \mathrm{vol})$, $300 \mu \mathrm{L}$ of ammonium persulphate $(10 \%)(\mathrm{wt} / \mathrm{vol})$ and $30 \mu \mathrm{L}$ of TEMED) were allowed to polymerize over $1.5 \mathrm{~h}$. Amplified DNA samples with the same volume of loading buffer $(10 \mu \mathrm{L}$ each) were separated by electrophoresis in $1.25 \times \mathrm{TAE}$ at a constant voltage (145 V) at a temperature gradient from $50{ }^{\circ} \mathrm{C}$ to $55^{\circ} \mathrm{C}$ with a temperature increment of 1 degree per hour. For bacteria, TGGE conditions 
differed by using $7 \%$ acrylamide gels ( $\mathrm{wt} / \mathrm{vol})$ and a temperature gradient from $58{ }^{\circ} \mathrm{C}$ to $63{ }^{\circ} \mathrm{C}$ with the same temperature increment. Gels were stained with ethidium bromide after electrophoresis and evaluated under UV light. Twenty of the most important fungal bands were excised from the gel and re-amplified with the previous primers set (non-clamped), purified (Quiagen purification kit) and sequenced (MWG Biotech). The DNA sequences obtained were compared to sequences available in the Genbank database of the National Centre Biotechnology Informatics (NCBI) using the Blast software.

\subsection{Statistics}

Species distribution and relative abundance were calculated based on data analyses using the Quantity One software (Biorad) with a position tolerance of $2 \mathrm{~mm}$, giving a maximum of 50 detectable species. Bands with intensities less than $5 \%$ of the intensity of the dominant band were excluded from the analysis. For each profile, the total number of species (species richness) and the Shannon-Wiener diversity index (referred to as SW hereafter) were calculated based on a natural logarithm transformation of the abundance data [10].

The significance of time and tree species on microbial species richness and SW diversity was tested by ANOVA using the Statistica software. The banding patterns of TGGE profiles were analyzed using multivariate techniques, reviewed in Fromin et al. [8]. These methods facilitate finding the variation in a multidimensional data set in a reduced space and assessing the association between species present and selected environmental factors. An initial DCA analysis was used to assess the trend of the data along the gradient. Because the structure was mostly linear, PCA and RDA were calculated using the square-root transformed relative abundances for each species in a profile. DCA and CCA were used in two cases of unimodal distribution. In the ordination plots presented, arrows indicate the direction in which the scores would move if the value of the environmental variable increased. The length of the arrows indicates the relative importance of the species/variable in explaining the variability between profiles. The angle between the arrows indicates the degree to which they are correlated. Monte Carlo permutation tests calculated the significance of a given factor. Forward selection was used to rank environmental variables in importance for determining the species data. All ordinations were computed using the Canoco software package. The significance level was set at $p<0.05$ for both the ANOVA and multivariable analyses.

\section{RESULTS}

\subsection{Fungal species richness and diversity}

All fifty potential fungal species were detected in the whole stands-time matrix. The number of species per TGGE profile ranged from 5 to 22 . Generally, the total number of species present in all stands increased with time from 36 species at the first sampling date to 45 after 2 years of incubation (Tab. I). The average number of species per sample exhibited the same trend (from 10.5 to 16.5 species detected) as did the average SW diversity index (0.866-1.083 in 4 months and 2 years, respectively). The only exception was the 8 month sampling, which had the lowest values of all of these characteristics. The

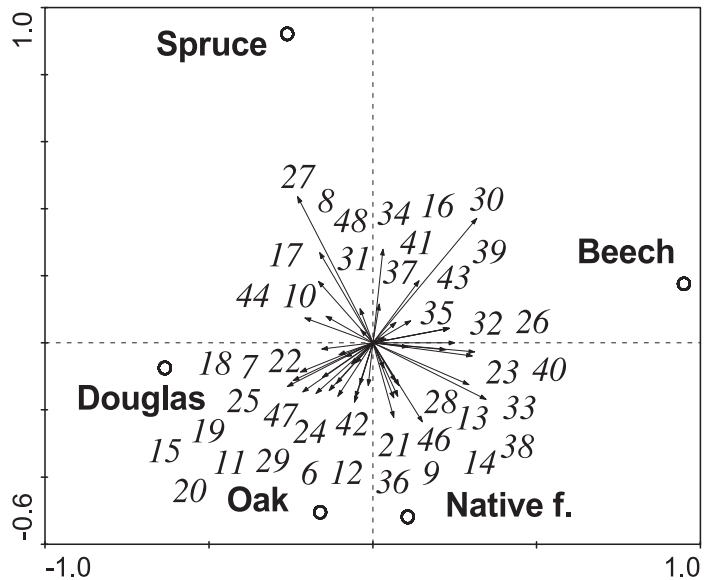

Figure 1. Fungal species distribution (arrows with numbers) and tree species position (circles and tree names) in ordination space according to the fungal community composition, based on the whole tree species-time matrix ( 5 tree species, 4 samplings together). Each arrow points in the direction of the steepest increase of abundance for the corresponding fungal species. The angles between arrows indicate correlations between them. The numbers correspond to the fungal species codes used in the text and Table II.

effect of time was found to be significant both for species richness and SW diversity $(p<0.001)$.

Tree species had a negligible influence on the total number of species detected, which varied from 40 to 43 within all the samplings (Tab. I). There were no significant differences either in average species richness or SW index for individual stands, although the native forest showed the highest measures (13.5 species in each sample, $\mathrm{SW}=0.993$ ) and the spruce site the lowest (only 11 species and SW $=0.904$ ). Intermediate values were found in the oak, beech and Douglas-fir stands (12.6 and $0.937 ; 12.3$ and $0.920 ; 12.2$ and 0.934 , respectively).

Twenty of the selected bands of the more common species were sequenced. The most similar species in the Genbank database are listed in Table II, together with the percent similarity to the reference sequences.

\subsection{Fungal community structure over time and among stands}

The first PCA component expressed $13.5 \%$ of the fungal species variability within all tree species and sampling dates. In RDA, the community composition was shown to be significantly affected by both time and tree species, together explaining $16.3 \%$ of total variation for the whole data set. A slightly higher weight could be noted for the tree species effect (8.8\%) than for the time effect $(7.5 \%)$. These values matched 9.5 and $8.2 \%$, respectively when analysed with the second factor as a covariable. Random tests confirmed the influence of both variables with $p$-values of 0.001 . Beech was the most discriminating tree species given by forward selection, followed by spruce, native forest, oak and Douglas-fir (Fig. 1).

Sampling dates were analysed separately (five tree stands together for each sampling date) in order to obtain a clearer 
Table I. Results of the multivariable analyses, together with the total number of species present, average species per sample ("richness") and Shannon-Wiener (SW) diversity index values. Scores for fungal communities in the sampling dates and tree species, for all stands and dates together, and bacterial diversity after 2 years are given. Variability explained by the 1st axis of indirect analyses (mostly PCA), all canonical axes (mostly RDA) and results of Monte Carlo permutation tests of stand or time effect (bold where significant) can be found.

\begin{tabular}{cccccccccc}
\hline & Data set & $\begin{array}{c}\text { Tested } \\
\text { effect }\end{array}$ & $\begin{array}{c}\text { Species } \\
\text { number }\end{array}$ & $\begin{array}{c}\text { Undirect } \\
\text { 1st axe }\end{array}$ & $\begin{array}{c}\text { Direct anal. } \\
\text { can. axes }\end{array}$ & $p$ value & F ratio & $\begin{array}{c}\text { Species } \\
\text { richness }\end{array}$ & $\begin{array}{c}\text { SW index } \\
\text { of diver sity }\end{array}$ \\
\hline F & All matrix & Time* & 50 & 13.5 & 8.2 & $\mathbf{0 . 0 0 1}$ & 4.807 & 12.3 & 0.937 \\
& All matrix & Stand* & 50 & 13.5 & 9.5 & $\mathbf{0 . 0 0 1}$ & 1.797 & $6-22^{* *}$ & $0.52-1.28^{* *}$ \\
F & 4 months & Stand & 36 & 22.5 & 39.5 & $\mathbf{0 . 0 1 0}$ & 1.629 & 10.5 & 0.866 \\
& 8 months & & 32 & 26.5 & 30.4 & 0.350 & 1.088 & 8.6 & 0.806 \\
& 12 months & & 42 & 19.1 & 42.3 & $\mathbf{0 . 0 0 2}$ & 1.829 & 13.6 & 0.995 \\
& 24 months & & 45 & 17.6 & 30.0 & 0.300 & 1.071 & 16.5 & 1.083 \\
F & Native f. & Time & 43 & 22.9 & 17.7 & $\mathbf{0 . 0 0 2}$ & 2.144 & 13.5 & 0.993 \\
& Spruce & $* * *$ & 40 & 21.5 & 14.7 & $\mathbf{0 . 0 1 8}$ & 1.700 & 11.0 & 0.904 \\
& Beech & $* * *$ & 41 & 22.0 & 12.0 & 0.076 & 1.340 & 12.3 & 0.920 \\
& Oak & & 40 & 24.2 & 15.9 & $\mathbf{0 . 0 1 6}$ & 1.188 & 12.6 & 0.937 \\
& Douglas & & 43 & 19.6 & 14.0 & $\mathbf{0 . 0 1 6}$ & 1.623 & 12.2 & 0.934 \\
\hline B & 24 months & Stand & 41 & 23.5 & 37.5 & $\mathbf{0 . 0 2 0}$ & 1.507 & 12.4 & 0.931 \\
\hline
\end{tabular}

* Unimodal analysis used (DCA and CCA), ** second effect (time or stand) as covariable, *** total range of values. F: Fungi; B: Bacteria.

Table II. Blast comparison of the sequenced bands. The most particular species (identity), their database match and percentage of similarity are given (sequenced fragments of 210-220 pb were compared).

\begin{tabular}{cccccc}
\hline Species n. & N. of samples & Identity & Blast match & Similarity \\
\hline 6 & 27 & Leaf litter ascomycete strain its408 isolate & A & AF502889 & 96 \\
7 & 37 & Megacollybia platyphylla & B & AF498289 & 100 \\
10 & 19 & Unpublished species & & - & - \\
12 & 32 & Epacris microphylla root associated fungus & & AY268197 & 98 \\
14 & 16 & Uncultured fungus clone B1c from forest & & AY324159 & 98 \\
17 & 23 & Leaf litter ascomycete strain its356 & A & AF502859 & 97 \\
19 & 17 & Trametes versicolor & B & AY673076 & 93 \\
21 & 27 & Gerronema strombodes & B & U66433 & 92 \\
23 & 16 & Phlebia albida & B & AY219368 & 94 \\
25 & 22 & Dactylaria sp. P24 & A & AY265332 & 88 \\
26 & 35 & B & AY219383 & 96 \\
28 & 26 & Fungal endophyte WMS13 & A & AY063309 & 94 \\
30 & 25 & Cryphonectria sp. CMW 11302 & A & AY214324 & 98 \\
33 & 10 & Epacrid root endophyte E4-5-5 & A & AF148952 & 91 \\
35 & 9 & Menispora tortuosa & A & AF178558 & 92 \\
37 & 10 & Coniosporium apollinis & A & AJ244271 & 90 \\
39 & 17 & Helotiales sp. sd2aN4b(A) & A & AY465452 & 95 \\
41 & 16 & Ascomycete sp. olrim349 & A & AY354279 & 95 \\
42 & 23 & A & AY230788 & 90 \\
46 & 11 & Woollsia root associated fungus XVIII & A & AF178544 & 94 \\
\hline
\end{tabular}

Species $\mathrm{n}$. is the number used in the text and images, N. of samples implies in how many samples the species was detected. A: Ascomycetes, B: Basidiomycetes. 


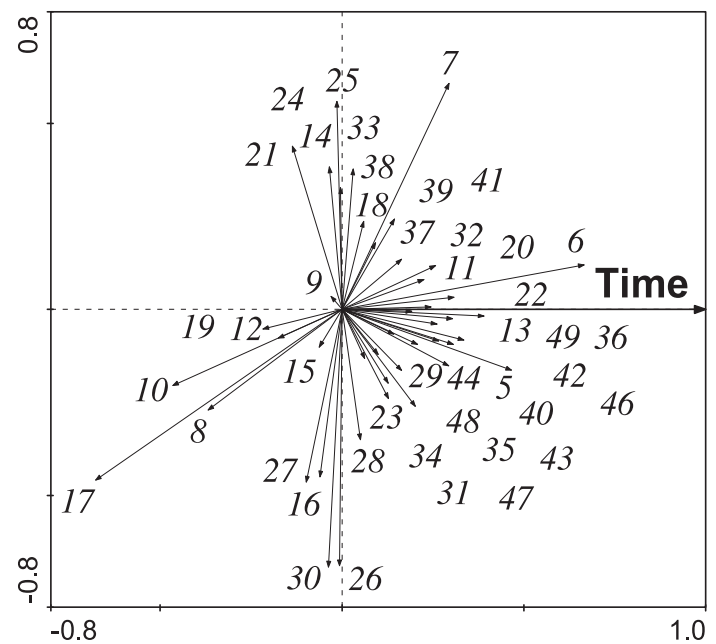

Figure 2. RDA bi-plot showing fungal species (arrows with numbers) responses and succession over time in all tree species together. The five tree species and four samplings were analysed together, with time as the independent variable (arrow connected to $\mathrm{x}$-axis).

picture of the relationship between fungal community composition and tree species effect. The tree species effect was detected as significant in the first and third samplings (4 and 12 months) (Tab. I). In those cases, the variability of community structure explained by RDA canonical axes also achieved higher values (39.5 and 42.3\%, respectively), the expressed portion was weaker (30.4 and $30.0 \%$, respectively) for non significant sampling times ( 8 and 24 months). A slight decrease in the importance of the first PCA axis appeared with time (from 22.5 to $17.6 \%$ ) with the exception of the 8th month sampling in late summer $2003(26.5 \%)$.

Simultaneously, the time effect on species succession was tested in individual tree stands (four sampling dates together in each tree stand) (Tab. I). Its significant influence was detected for all tree species except beech, where a trend could still be seen $(p=0.076)$. Beech, together with spruce, also displayed a non-linear species distribution along the time gradient so that unimodal analyses (DCA) had to be used. The first component of the indirect analyses explained from 19.6 to $22.9 \%$ of the variability, whereas it ranged between 12.0 and $17.7 \%$ for linear techniques. The largest portion of the temporal community evolution was expressed for oak and native forest by both analyses.

There was a relationship between fungal species numbers and occurrence with particular tree species (Fig. 1). Fungal species numbers also changed over time (Fig. 2). Fungal community composition differed clearly among tree stands both in the first (Fig. 3a, 4 months) and the last (Fig. 3b, 2 years) sampling time. A distinct temporal shift can be detected. Coniferous and deciduous stands were separated along the y-axis in the first sampling period. This trend was less obvious in the last sampling, with the native forest situated above the x-axis. Coniferous stands tended to occupy the upper left portion of the ordination plane in both cases even when the Douglas-fir site displayed only low species specificity later. There were

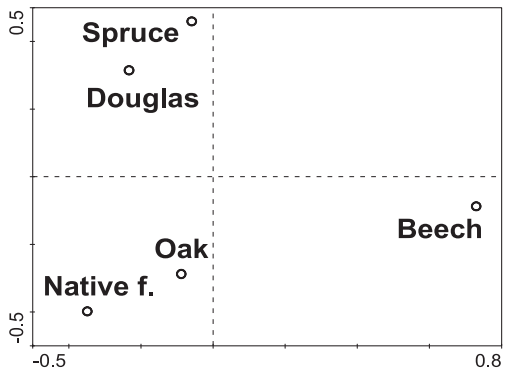

(a)

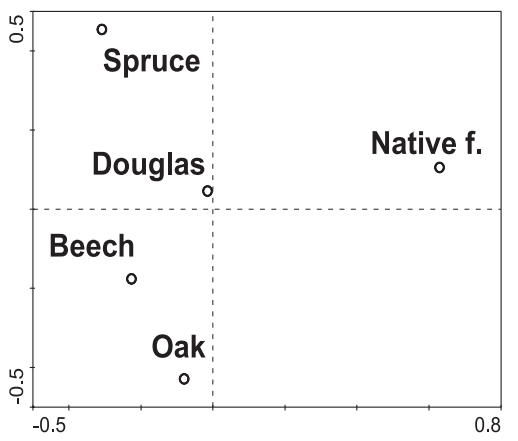

(b)

Figure 3. RDA ordination plots illustrating the tree species position at (a) the first sampling time (4 months) and (b) the last sampling time (24 months) according to the fungal species distribution.

noticeable shifts in the young beech and native forest stands. At the beginning of the study, a specific fungal community was found in the beech stand while its structure in the native forest was similar to that in the oak stand. By the end, the native forest had a separate species structure and the young broadleaf monocultures were grouped together.

\subsection{Stand condition effect on fungal communities}

There were definite relationships between tree species and their environment, as shown by the PCA of the important characteristics of forest floor, upper soil layer and soil solution (Fig. 4). The native forest, young broadleaf monocultures and coniferous stands were well separated along the $\mathrm{x}$-axis. The oak site was positioned separately along the y-axis in the upper right quarter.

The importance of soil temperature and moisture were tested separately, based on average values for the month before sampling. The native forest was not included in the analyses because of missing data. Both factors had significant impacts on the species composition ( $p=0.002$ for both) and explained 5.7 and $5.8 \%$ of the total data set variability, respectively. As expected, temperature and moisture were correlated.

\subsection{Bacterial communities}

Forty-one different bacterial species from the 50 potentially detectable ones were found under the different tree species in 


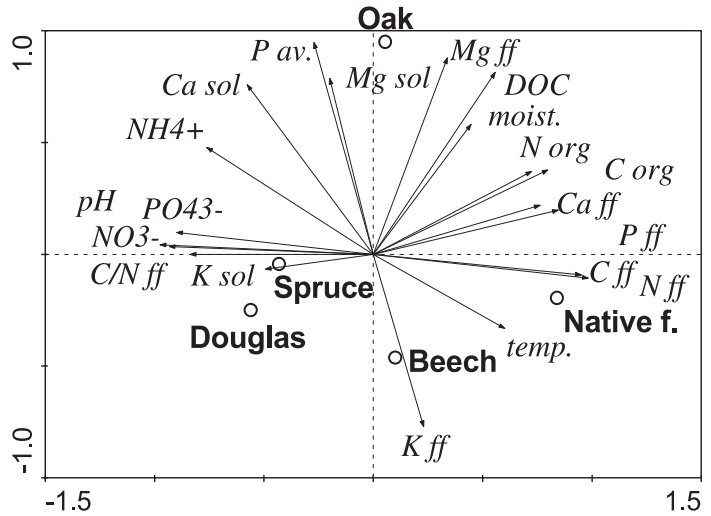

Figure 4. PCA ordination plot displaying relations of the environmental variables (arrows) in the studied tree species. ff means nutrient concentration in forest floor $(\mathrm{C}, \mathrm{N}, \mathrm{C} / \mathrm{N}, \mathrm{P}, \mathrm{K}, \mathrm{Ca}, \mathrm{Mg})$; sol means concentration in soil solution in the top $5 \mathrm{~cm}(\mathrm{~K}, \mathrm{Ca}, \mathrm{Mg})$. Other variables in solution are also shown $\left(\mathrm{pH}, \mathrm{PO}_{4}^{3-}, \mathrm{NO}^{3-}, \mathrm{NH}^{4+}, \mathrm{DOC}\right)$; concentrations of available $\mathrm{P}$, organic $\mathrm{C}$ and $\mathrm{N}$ were also measured in the top $5 \mathrm{~cm}$ of the soil profile. The length of arrow indicates the relative importance of the variable in explaining the position of the tree species in the ordination space. The angle between the arrows indicates the degree to which they are correlated.

the last sampling time ( 24 months). There were 12.4 species on average per sample. The highest species richness was detected in the native and oak forests (24 different species), followed by beech (23), Douglas-fir (22) and spruce (20 species). The native forest also had the highest average number of species present per sample (14), followed by oak (12.7), spruce (12.3), Douglas-fir (11.7) and lastly beech (11.3). The highest diversity index value was also associated with the native forest (SW $=0.998)$, followed by the conifers and oak (approximately 0.95), with the lowest rate in beech (0.745). However, the influence of tree species on bacterial species richness and diversity was not significant.

The first PCA component explained $23.5 \%$ of the bacterial data set variability. The canonical axes of RDA, with tree species as independent variables, expressed $37.6 \%$ of the variability. Permutation tests showed a significant influence of tree species on the bacterial community composition $(p=0.02$, Tab. I). The distribution of the tree species, as a function of bacterial species distribution, showed a clear separation along the visualized axes (Fig. 5). The native forest appeared to have a similar bacterial composition as the spruce stand. Young deciduous monocultures were grouped in the lower left part of the plot while the Douglas-fir stand differed clearly from the others, being located in the upper left quarter. The Douglas-fir stand was the most discriminating, based on the forward selection of environmental variables, followed by oak and then the three other stands.

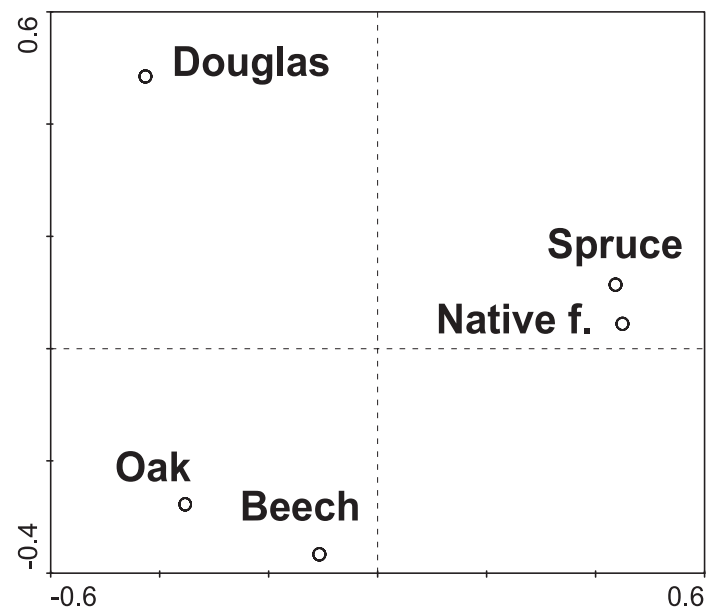

Figure 5. RDA ordination plot showing tree species position according to bacterial species distribution after 2 years of samples colonisation. The native forest and spruce did not differ either by position on the $\mathrm{x}$ or $\mathrm{y}$-axis and thus they had similar bacterial communities.

\section{DISCUSSION}

\subsection{Molecular approach}

The fungal ITS region was targeted because it appeared to be taxonomically more informative than other genomic regions [19]. We also tried the $18 \mathrm{~S}$ amplification with the same DNA samples. The number of visible bands after electrophoresis was lower than in the case of ITS. In addition Anderson et al. [2] noted that the ITS1F and ITS2 primers gave the sharpest and most consistent electrophoresis profiles in their fungal diversity study in organic soils. The primer pair efficiently amplified both asco- and basidiomycetes species in the present study as well as in Gardes and Bruns' study [9]. TGGE has been shown to be a sensitive and robust method for investigating soil fungal communities, particularly where the aim was to investigate shifts or changes in community composition $[1,30]$. The ordination methods allowed comparison of both the position and the relative intensity of different bands within gels, as well as the interpretation of ecological significance [8].

In total, 20 fungal bands were sequenced and compared to similar sequences present in the GenBank database. A certain limitation imposed by existing databases must be noted when characterizing natural communities. Therefore, blasting did not completely provide determination at the species level. The majority of sequences had a high similarity to the fungal ITS sequences of the database. However, four of them matched uncultured fungi generated from previous molecular studies, but were not named to species, while one sequence had no similarity to any in the database. Despite only approximate identification, it was assumed that all sequences belonged to fungal species that occur in forest stands and are mostly saprophytic. It is also possible that there are un-cultivable species present, which are not currently represented in databases.

It was also realized that single bands did not necessarily originate from one species and that one band could contain 
different sequences [20]. We tried to sequence several bands at the same position, as well as to have more replicates of the same bands. The results obtained by the sequencing were always similar. Thus, it was possible to assume that TGGE provided a quick and high resolution in the separation of microbial DNA fragments.

It is likely that the decomposer community present in the forest soil, as well as the site conditions, were more important for the resulting diversity than the origin of the incubated material (beech-wood). Thus, both non specific and specific fungi should be present in all of the stands. An advantage of this is that it gives the ability to compare situations using only a single probe. Nevertheless, it is a disadvantage to use a model material which is one of the set of species being investigated. It would be interesting to make a comparison with a wood probe from a different species. It has been documented that fungal mycelial ingrowths and the rates of mass loss and respiration could differ with litter material when incubated in the same site [31]. The sample size used in the study should be adequate to ensure high diversity, since small diameter debris has a relatively larger surface area per volume than larger ones [11]. Accordingly, Kruys and Jonsson [17] found smaller spruce logs to host more cryptogams than logs with diameters over $10 \mathrm{~cm}$. Moreover, spatial heterogeneity within the soil is high and can be linked to the distribution of micro-organisms; there is a close relationship between sampling strategy and the observed species richness [28]. However, the PCA analyses (not shown) confirmed high variability of diversity between stands but a relatively low variability between sample replicates. Therefore, our design recorded well the species distribution patterns.

\subsection{Tree species and time effect}

Each tree species, as well as sampling time, displayed a characteristic fungal community structure. The effect of both factors was highly significant. Oak and native forest had quite similar species structure over the whole observation period. There were also other species that are present in other stands, except for spruce whose species composition was highly specific. Douglas-fir had some species in common with Norway spruce but tended to converged more towards the oak site. There was very little species overlap between Douglas-fir and beech at the same time. The species composition of the young beech stand was rather similar to the community observed in the native forest. Nevertheless, both beech and spruce stands had fewer species that were common in the three other stands.

The fungal communities in some particular spruce and Douglas-fir samples seemed to be less variable than over the whole period of incubation. This might be caused by the presence of some species typical for coniferous sites at a given time (e.g. species 10 or 17). There were clear shifts over time in the fungal communities of the native forest and beech stands. At the beginning of the incubation, the fungal species composition of the native forest resembled that of oak, while the beech fungal communities were distinct from these stands. The situation was reversed in the last sampling. Similar fungi were present in the young deciduous monocultures whereas the native forest had a unique species composition. This might not be so surprising, because the native stand was composed of both oak and beech trees. Rather, it could reflect the presence of several species typical for broadleaf stands but differing in certain ecological demands (e.g. species 42, present in the native forest at first, but in the oak and beech monocultures at the end) or to the greater importance of ecological conditions in earlier rather than later stages of decay. This could be determined by the analyzing the stands distribution in relation to environmental variables (Fig. 4) and within the first sampling time (Fig. 3a). Interestingly, the time effect was highly significant in the oak and native stands whereas the beech was the only one where its role was not evident. Moreover, several characteristic of the native forest, such as a greater amount of dead wood on the forest floor, age differentiation of the trees, species mixture and more energy reaching the soil surface, would support greater niche complementarity for both specialist and generalist fungal species.

Both species richness and SW diversity clearly increased over time. No substantial changes between the stands were found in overall quantity of species present during the whole period. Nevertheless, the average species number per sample was slightly higher in the native forest and lowest in spruce. Even though no significant decrease was observed in the wood-colonizing species number caused by a change in tree species, other ecological effects could be expected. For example, microbial biomass could be reduced in response to less favourable litter quality or certain functional changes might occur. Previous studies in the same research site [23] showed the highest amount of both saprophytic and ectomycorrhizal fungal species occurred in the native forest (104 species together), while the lowest was in the oak and beech stands (26 species only). Lejon et al. [18], using the ARISA molecular approach, also showed a strong discrimination of fungal communities under the studied tree species. They showed by comparing that the microbial biomass in the upper layer was highest in the native forest, followed by oak, spruce and Douglas-fir (beech was not included) [18]. Plant species richness was also highly affected [23], being highest in the oak stand followed by beech, spruce and Douglas, with 16, 10, 7 and only 2 species present in the under-storey respectively (no data was available for native forest).

Several recent studies have screened macro-fungal species richness on decaying wood. Bader et al. [5] found the greatest number of species at intermediate stages of wood decay and a negative correlation between species number and logging activities in a Swedish boreal forest. Accordingly, HeilmannClausen and Christensen [12] detected a decrease in fungal species number with forest age in beech sites in Denmark. This could be caused by a loss of weakly competitive nonspecialized species, to the benefit of highly competitive or narrow niche specialists, as the fungal community matures, whereas wood that has started to soften may contain a mixture of early, intermediate and late successional species. A meta-analysis of diversity studies showed high macro-fungal diversity associated with high tree species richness [25]. Rodriguez et al. [24] found no significant difference in the total 
population of lignin and lignocellulosis degrading fungi imperfecti from laurel and pine forests on Tenerife. Species of Penicillium and Fusarium were identified as the most efficient lignin degraders. Cox et al. [7] illustrated the importance of the effects and interactions of specific fungi during lignin decomposition in a Scots pine forest.

Bacterial communities were also specific for each forest stand. The greatest numbers of species were detected in native and oak stands, followed by beech and conifers. Accordingly, the highest average species number per sample was in the native forest whereas the beech site had the lowest value. Similarly as for fungi, ARISA profiles showed that tree species induced a specific genetic structure of the bacterial communities [18].

\subsection{Fungal species patterns}

Ascomycetes comprised the highest portion of identified fungi rather than basidiomycetes. Nordén et al. [21] found more basidiomycetes than ascomycetes species in their study of wood-inhabiting fungi in temperate broadleaved forests. However, their study was based on recording stroma and fruitbody diameters of $1 \mathrm{~mm}$ or more. The molecular approach could offer a for more reliable detection of fungal mycelium in belowground wood debris than the distribution of fruit bodies [15].

Five of the fifty defined fungal species occurred only once (these were not shown in the ordination plots), while twelve species occurred in more than one third of all samples. The most abundant were species 7, 26 and 12, appearing in 37, 35 and 32 TGGE profiles, respectively. The most common species (number 7) was identified as Megacollybia platyphylla, the order Agaricales. This was the only one with a $100 \%$ similarity with the Genebank database. It was also the only species detected in the same forest site where carpophore diversity was studied [23]. Twenty-eight species were found in all sampling times and 31 under all tree species. The 23 species representing the intersection of these categories were present in all stands in all sampling times, but varying in the number of occurrences. Some species were associated with coniferous species (e.g. 7, 8, 10, 17, 27 or 44), young deciduous trees (14, $26,28,33,38,40,45)$ or with the native forest $(9,23,29,36$ and 49). Others seemed to prefer sites dominated by beech, i.e. native forest and young monoculture $(13,23,39)$. Species $(8$, 10,17 or 19) were identified mostly in the early stages of colonization (Fig. 2). Species $(6,13,36,40,42,46)$ were positively correlated with the later stages. Species appearing largely in intermediate periods were distributed along the positive part of the $y$-axis $(14,21,24,25,33)$.Species mostly absent during the second sampling $(26,28,30)$ were in the negative range. Species which showed no time response are presented only by short arrows $(9,15,23)$. Only a few fungi species displayed no or only weak tree stand or sampling time preferences (e.g. 11, $12,15,16,18$ and 31).

For bacteria, nine of forty-one species occurred at least once in each tree species after 2 years of incubation. Five species were present in more than two-thirds of the TGGE profiles. Conversely, 12 species appeared in only one profile. Also, characteristic bacteria species for different stands could be found.

\subsection{Relation with environmental conditions}

All differences in the studied forest site conditions were assumed to be caused by the dominant tree species, because geology and meso-climate conditions were very homogenous and site histories were the same (plantations were made after clear-cutting the broadleaf semi-native forest). Coniferous stands appeared to have certain specific characteristics when compared to broadleaved stands three decades after plantation establishment. They had low concentrations of total organic carbon and nitrogen in the forest floor and higher $\mathrm{C} / \mathrm{N}$ ratios. Coniferous stands also had higher $\mathrm{pH}$ of the soil solution and phosphate and potassium concentrations. There was more inorganic nitrogen in the spruce and Douglas-fir stands. Douglas-fir stands displayed extremely high concentrations of nitrates. On the contrary, both nitrate and ammonium concentrations were very low in the native forest, as was phosphate content. Low $\mathrm{pH}$ was also typical of the native forest.

Conifers had the lowest phosphorus and potassium amounts in the forest floor. Oak had a nutrient-rich forest floor, which could lead to higher concentrations of organic carbon and nitrogen in the humus, together with high amounts of DOC, ammonium, available phosphorus, calcium and magnesium. Beech seemed to have intermediate values for most of these characteristics.

Native and beech forests differed in stand age and certain ecological characteristics, but had similar dominant species. The native forest could be assumed to be a climax-like ecosystem with well balanced processes unlike in the young monocultures, as shown by the high values of mineral nitrogen and phosphorus in conifers, compared to the strong retention of organic forms in the native forest.

Physical conditions that significantly changed according to season, such as temperature and moisture, might control both species composition and their decaying activity. Meso and pedo climatic conditions (air temperature and relative humidity, soil temperature and moisture) were monitored continuously since 2001 [23]. Beech was the warmest stand in all samplings, spruce the coldest one, while oak and Douglas-fir were intermediate (no data for the native forest). The highest soil moisture content was observed in the oak site, followed by spruce and beech, with lower soil moistures observed in the Douglas-fir $[4,34]$. Thus, the oak and spruce stands were relatively cold and humid, while the beech and Douglas fir stands were warmer and drier [23]. The soil conditions at the first sampling time in late February 2003 were the coldest and most humid of all. Conditions were slightly drier and warmer in the late November samplings. The second sampling in September 2003 occurred during extremely warm and dry conditions. The effect of both soil temperature and moisture content was significant, even though these factors were less discriminating for community composition than tree species and time. 
Cold or dry months could cause a reduction in species richness or fungal biomass. Such conditions would also favour less competitive species allowing them to be detected in profiles. This was noted in the second sampling time in September 2003, which followed an extremely warm and dry summer period. For that sampling time, species number was lower and the structure was different from the general trend with some characteristic species present only there. Such a seasonal variation, if present at all, was dependent more on the site conditions than on the tree species effect. The influence of environmental conditions could also change with the decay phase, being greatest in the early stages [6]. On the contrary, the stand effect was not significant even in the last sampling.

\section{CONCLUSION}

Each tree stand and sampling time had the characteristic wood decomposer species community structure. There was no strong decrease of microbial species number caused by change of tree dominant but strong shift in community structure was evident. In order to better understand the complex effect of tree species change it is necessary to consider also other factors, such as functional diversity, biodiversity of other organisms or fungal groups, soil development or ecosystem function at the landscape level. Thus more research is still needed in this field.

Acknowledgements: The authors thank the technician team of the INRA "Biogéochimie des Écosystèmes Forestiers" Unit, in charge of building the database of the site, Dominique Gelhaye, responsible for the experimental site, and Séverine Bienaime, Pascal Bonnaud, Louisette Gelhaye and Benoît Pollier for laboratory assistance. The authors thank also GIP-Ecofor for providing subsidies for monitoring the Breuil site experiment, the French Ministry of Research for supporting the "Effet des substitutions d'essences et de l'augmentation du $\mathrm{CO}_{2}$ atmosphérique sur les communautés microbiennes intervenant dans le fonctionnement d'un écosystème forestier" project coordinated by Dr Francis Martin (UMR Interactions Arbres Microorganismes), the Marie-Curie association (grant fellowship of Ariana Kulhánková in 2004) and the Czech Science Foundation (grant No. 206/03/H137). We are also very grateful to Marta Ruth and Keith Edwards for the language corrections.

\section{REFERENCES}

[1] Anderson I.C., Cairney J.W.G., Diversity and ecology of soil fungal communities: increased understanding through the application of molecular techniques, Environ. Microbiol. 6 (2004) 769-779.

[2] Anderson I.C., Campbell C.D., Prosser J.I., Diversity of fungi in organic soils under a moorland - Scots pine (Pinus sylvestris L.) gradient, Environ. Microbiol. 5 (2003) 1121-1132.

[3] Aneja M.K., Sharma S., Munch J.C., Schloter M., RNA fingerprinting - a new method to screen for differences in plant litter degrading microbial communities, J. Microbiol. Meth. 59 (2004) 223-231.

[4] Aussenac G., Interactions between forest stands and microclimate: Ecophysiological aspects and consequences for silviculture, Ann. For. Sci. 57 (2000) 287-301.
[5] Bader P., Jansson S., Jonsson B.G., Wood-inhabiting fungi and substratum decline in selectively logged boreal spruce forests, Biol Conserv. 72 (1995) 355-362.

[6] Berg B., McClaugherty C., Plant litter - decomposition, humus formation, carbon sequestration, Springer-Verlag, Berlin, 2003.

[7] Cox P., Wilkinson S.P., Anderson J.M., Effects of fungal inocula on the decomposition of lignin and structural polysaccharides in Pinus sylvestris litter, Biol. Fertil. Soils 33 (2001) 246-251.

[8] Fromin N., Hamelin J., Tarnawski S., Roesti D., Jourdain-Miserez K., Forestier N., Teyssier-Cuvelle S., Gillet F., Aragno M., Rossi P., Statistical analysis of denaturing gel electrophoresis (DGE) fingerprinting patterns, Environ. Microbiol. 4 (2002) 634-643.

[9] Gardes M., Bruns T.D., ITS primers with enhanced specificity for basidiomycetes: application to the identification of mycorrhizae and rusts, Mol. Ecol. 2 (1993) 113-118.

[10] Griffiths B.S., Ritz K., Wheatley R., Kuan H.L., Boag B., Christensen S., Ekelund F., Sorensen S.J., Muller S., Bloem J., An examination of the biodiversity-ecosystem function relationship in arable soil microbial communities, Soil Biol. Biochem. 33 (2001) $1713-1722$.

[11] Heilmann-Clausen J., Christensen M., Does size matter? On the importance of various dead wood fractions for fungal diversity in Danish beech forests, Forest Ecol. Manage. 201 (2004) 105-119.

[12] Heilmann-Clausen J., Christensen M., Wood-inhabiting macrofungi in Danish beech-forests - conflicting diversity patterns and their implications in a conservation perspective, Biol. Conserv. 122 (2005) 633-642.

[13] Heuer H., Smalla K., Application of denaturing gradient gel electrophoresis and temperature gradient gel electrophoresis for studying soil microbial communities, in: van Elsas J.D., Wellington E.M.H., Trevors J.T. (Eds.), Modern Soil Microbiology, Marcel Dekker, Inc., New York, 1997, pp. 353-373.

[14] Jasalavich C.A., Ostrofsky A., Jellison J., Detection and identification of decay fungi in spruce wood by restriction fragment length polymorphism analysis of amplified genes encoding rRNA, Appl Environ. Microbiol. 66 (2000) 4725-4734.

[15] Johannesson H., Stenlid J., Molecular identification of woodinhabiting fungi in an unmanaged Picea abies forest in Sweden, Forest Ecol. Manage. 115 (1999) 203-211.

[16] Karén O., Hogberg N., Dalgberg A., Jonsson L., Nylund J.E., Interand intraspecific variation in the ITS region of rDNA of ectomycorrhizal fungi in Fennoscandia as detected by endonuclease analysis, New Phytol. 136 (1997) 313-325.

[17] Kruys N., Jonsson B.G., Fine woody debris is important for species richness on logs in managed boreal spruce forests of northern Sweden, Can. J. Forest Res. 29 (1999) 1295-1299.

[18] Lejon D.P.H., Ranger J., Chaussod R., Ranjard L., Effect of tree species on the density and genetic structure of microbial communities in an acid forest soil (Morvan, France), Microb. Ecol. (in press).

[19] Lord N.S., Kaplan C.W., Shank P., Kitts C.L., Elrod S.L., Assessment of fungal diversity using terminal restriction fragment (TRF) pattern analysis: comparison of $18 \mathrm{~S}$ and ITS ribosomal regions, FEMS Microbiol. Ecol. 42 (2002) 327-337.

[20] Muyzer G., DGGE/TGGE a method for identifying genes from natural ecosystems, Curr. Opin. Microbiol. 2 (1999) 317-322.

[21] Nordén B., Ryberg M., Gotmark F., Olausson B., Relative importance of coarse and fine woody debris for the diversity of woodinhabiting fungi in temperate broadleaf forests, Biol. Conserv. 117 (2004) $1-10$.

[22] Osono T., Takeda H., Organic chemical and nutrient dynamics in decomposing beech leaf litter in relation to fungal ingrowth and succession during 3-year decomposition processes in a cool temperate deciduous forest in Japan, Ecol. Res. 16 (2001) 649-670. 
[23] Ranger J., Andreux B.S.F., Berthelin B.P., Boudot J.P., Bréchet C., Buée M., Calmet J.P., Chaussod R., Gelhaye D., Gelhaye L., Gérard F., Jaffrain J., Lejon D., Le Tacon F., Léveque J., Maurice J.P., Merlet D., Moukoumi J., Munier-Lamy C., Nourrisson G., Pollier B., Ranjard L., Simonsson M., Turpault M.P., Vairelles D., Zeller B., Effet des substitutions d'essence sur le fonctionnement organo-minéral de l'écosystème forestier, sur les communautés microbiennes et sur la diversité des communautés fongiques mycorhiziennes et saprophytes (cas du dispositif expérimental de Breuil-Morvan). Final report of contract INRA-GIP Ecofor 200124, N INRA 1502A, INRA BEF Nancy, Champenoux, 2004.

[24] Rodriguez A., Perestelo F., Carnicero A., Regalado V., Perez R., De la Fuente G., Falcon M.A., Degradation of natural lignins and lignocellulosic substrates by soil-inhabiting fungi imperfecti, FEMS Microbiol. Ecol. 21 (1996) 213-219.

[25] Schmit J.P., Mueller G.M., Leacock P.R., Mata J.L., Wu Q., Huang Y., Assessment of tree species richness as a surrogate for macrofungal species richness, Biol. Conserv. 121 (2005) 99-110.

[26] Setala H., McLean M.A., Decomposition rate of organic substrates in relation to the species diversity of soil saprophytic fungi, Oecologia 139 (2004) 98-107.

[27] Setala H., Aarnio T., Vertical stratification and trophic interactions among organisms of a soil decomposer food web - a field experiment using $15 \mathrm{~N}$ as a tool, Eur. J. Soil Biol. 38 (2002) 29-34.

[28] Taylor A.F.S., Fungal diversity in ectomycorrhizal communities: sampling effort and species detection, Plant Soil 244 (2002) 19-28.
[29] Vainio E.J., Hantula J., Direct analysis of wood-inhabiting fungi using denaturing gradient gel electrophoresis of amplified ribosomal DNA, Mycol. Res. 104 (2000) 927-936.

[30] Van Elsas J.D., Duarte G.F., Keijzer-Wolters A., Smit E., Analysis of the dynamics of fungal communities in soil via fungal-specific PCR of soil DNA followed by denaturing gradient gel electrophoresis, J. Microbiol. Meth. 43 (2000) 133-151.

[31] Virzo De Santo A., Rutigliano F.A., Berg B., Fioretto A., Puppi G., Alfani A., Fungal mycelium and decomposition of needle litter in three contrasting coniferous forests, Acta Oecol. 23 (2002) 247259.

[32] White T.J., Bruns T.D., Lee S.B., Taylor J.W., Amplification and direct sequencing of fungal ribosomal RNA Genes for phylogenetics, in: Innis N., Gelfand D., Sninsky J., White T. (Eds.), PCR - Protocols and Applications - A Laboratory Manual, Academic Press, New York, 1990, pp. 315-322.

[33] Wilkinson S.C., Anderson J.M., Scardelis S.P., Tisiafouli M., Taylor A., Wolters V., PLFA profiles of microbial communities in decomposing conifer litters subject to moisture stress, Soil Biol. Biochem. 34 (2002) 189-200.

[34] Yang Y.S., Chen G.S., Guo J.F., Lin P., Decomposition dynamic of fine roots in a mixed forest of Cunninghamia lanceolata and Tsoogiodendron odorum in mid-subtropics, Ann. For. Sci. 61 (2004) 65-72. 